\title{
SARS-COV-2 antibody prevalence in patients on dialysis in the US in January 2021
}

Authors:

Shuchi Anand, MD, Department of Medicine (Nephrology), Stanford University

Maria Montez-Rath, PhD, Department of Medicine (Nephrology), Stanford University

Jialin Han, MS, Department of Medicine (Nephrology), Stanford University

LinaCel Cadden, CLS, Ascend Clinical Laboratory

Patti Hunsader, CLS, Ascend Clinical Laboratory

Russell Kerschmann, MD, Ascend Clinical Laboratory

Paul Beyer, MBA, Ascend Clinical Laboratory

Scott D Boyd, MD, PhD, Department of Pathology, Stanford University

Pablo Garcia, MD, Department of Medicine (Nephrology), Stanford University

Mary Dittrich, MD, US Renal Care

Geoffrey A Block, MD, US Renal Care

Julie Parsonnet, MD, Departments of Medicine (Infectious Diseases and Geographic Medicine), and Epidemiology and Population Health, Stanford University

Glenn M Chertow, MD, Departments of Medicine (Nephrology), and Epidemiology and Population Health, Stanford University 


\begin{abstract}
Background: To estimate seroprevalence of SARS-CoV-2 antibodies in the US, the country with the world's largest absolute numbers of COVID19 cases and deaths, we conducted a cross-sectional assessment from a sample of patients receiving dialysis in January 2021.

Methods: We tested remainder plasma of 21,424 patients receiving dialysis through the third-largest US dialysis organization, with facilities located nationwide. We used the Siemens spike protein receptor binding domain total antibody assay to estimate crude SARS-CoV-2 seroprevalence, and then estimated seroprevalence for the US dialysis and adult population by standardizing by age, sex and region. We also compared January 2021 seroprevalence and case-detection rates to that from a similar subsample of patients receiving dialysis who had been tested in July 2020.

Results: Patients in the sample were disproportionately from older age and minority race/ethnic groups. Seroprevalence of SARS-CoV-2 was $18.9 \%$ (95\% CI: 18.3-19.5\%) in the sample, $18.7 \%$ (18.1-19.2\%) standardized to the US dialysis population, and 21.3\% (20.3-22.3\%) standardized to the US adult population (range 15.3-20.8\% in the Northeast and South respectively). Younger age groups (18-44 years), and persons self-identifying as Hispanic or living in Hispanic neighborhoods, and persons living in the poorest neighborhoods were among the subgroups with the highest seroprevalence $(25.9 \%$ (24.1$27.8 \%$ ), $25.1 \%$ (23.6-26.4\%), 24.8\% (23.2-26.5\%) respectively). Compared to data from July 2020, we observed diminished variability in seroprevalence by geographic region and urban-rural status. Estimated case detection rate increased from 14\% to 23\% in July 2020 to January 2021.

Conclusions: A year after the first case of SARS-CoV-2 infection was detected in the US, fewer than one in four adults have evidence of SARS-CoV-2 antibodies. Vaccine roll out to majority minority neighborhoods and poorer neighborhoods will be critical to disrupting the spread of infection.
\end{abstract}

Funding: Ascend Clinical Laboratories funded remainder-plasma testing. 
medRxiv preprint doi: https://doi.org/10.1101/2021.03.07.21252786; this version posted March 9, 2021. The copyright holder for this preprint (which was not certified by peer review) is the author/funder, who has granted medRxiv a license to display the preprint in perpetuity.

All rights reserved. No reuse allowed without permission.

\section{Introduction}

In the year-long period since SARS-CoV-2 case was reported in the US, COVID-19 cases, deaths, and hospitalizations overwhelmed health systems in the country. To date, more than 25 million cases and 500,000 deaths have been attributed to SARS-CoV-2 infection ${ }^{1,2}$. While in Spring 2020, the most intense burden of disease was experienced in and around the state of New York, nearly all regions in the US including rural areas have recently faced threats to their hospital capacity, with the largest numbers accruing between November and December $2020^{2}$.

Data continue to support that symptomatic cases represent a fraction of persons infected with SARS-CoV$2^{3}$. The vast majority of persons with infection, however, whether asymptomatic or symptomatic, do mount a specific antibody response ${ }^{4-6}$, with the latest data indicating SARS-CoV-2 receptor binding domain (RBD) IgG antibodies persist for at least four to six months after infection ${ }^{4,7,8}$. Thus, seroprevalence estimates remain an essential measure of the extent of SARS-CoV-2 community spread.

Following our proposed strategy of performing repeated seroprevalence surveys among patients on dialysis, a population broadly representative of groups susceptible to SARS-CoV-2 infection and among whom routine requirements for monthly laboratories facilitates surveillance ${ }^{9}$, we implemented a crosssectional seroprevalence analysis in a sample of 21,424 patients on dialysis in the US in January 2021. Our goal was to assess SARS-CoV-2 seroprevalence prior to widespread roll out of COVID19 vaccination. We also tested the persistence of previously observed differences in seroprevalence by region, age, sex, race/ethnicity, and other community-level strata of interest including population density and neighborhood poverty. Finally, to assess for improvements in diagnosis and treatment since our July survey, we compared case detection attributed to COVID19 to our seroprevalence estimates at the July 2020 and January 2021 timepoints. 


\section{Methods}

We replicated methods presented previously ${ }^{9}$, including the use of a highly sensitive and specific total RBD total antibody assay on remnant plasma from routine monthly laboratory draws. The primary difference was in the sample population. Previously, samples were obtained from multiple dialysis networks and from patients residing in 46 states. The current sample derived from a single national dialysis network, US Renal Care, the third largest dialysis center in the US with 518 facilities and from patients residing in 43 states. We tested all patients $(n=21424)$ within this single dialysis network in preparation for a longitudinal study being conducted in this network to ascertain response to COVID19 vaccination.

The study received Institutional Review Board Approval from Stanford University.

\section{Assay characteristics}

In partnership with a commercial laboratory receiving routine monthly laboratories of patients on dialysis, we tested the remnant plasma of all patients receiving dialysis through US Renal Care. We used the Siemens RBD total antibody (Ig) chemiluminescence assay, which has $100 \%$ sensitivity $(\geq 14$ days post + PCR test) and $99.8 \%$ specificity ${ }^{10}$.

\section{Statistical analyses}

We determined seroprevalence estimates and $95 \%$ confidence intervals for the crude (unweighted) sample from January 2021. We then standardized seroprevalence estimates accounting for age, sex, and region, using the distribution of the US dialysis population as available through the United States Renal Data System $^{11}$ and for the US adult population as available through the 2018 American Community Survey 1-

year estimates ${ }^{12}$. Next we examined differences in seroprevalence by the following strata: age, sex, region, self-reported race/ethnicity, neighborhood race/ethnicity composition, neighborhood poverty, and urban/rural status ${ }^{9}$. 
medRxiv preprint doi: https://doi.org/10.1101/2021.03.07.21252786; this version posted March 9, 2021. The copyright holder for this preprint (which was not certified by peer review) is the author/funder, who has granted medRxiv a license to display the preprint in perpetuity.

All rights reserved. No reuse allowed without permission.

We also compared data on differences in seroprevalence by patient and neighborhood characteristics and region of residence strata to the observed differences in July 2020. To ensure accurate comparisons, we limited the July 2020 sample to those obtained within US Renal Care ( $\mathrm{n}=11,746(41 \%)$ of 28,503 tested in July,supplemental Table 1).

Finally, we compared case detection and infection fatality rates in July 2020 versus January 2021 . We computed case detection rates as the proportion of detected cases per $100,000^{2}$ from a denominator totaling seroprevalence estimates per 100,000 (standardized to the US adult population) and deaths per 100,000 in January 1 2020-June 31 2020, and July 1 2020-December 312020 for the July 2020 and January 2021 estimates respectively. We adjusted the numerator of detected cases to reflect adults only using Centers for Disease Control data on proportion of overall cases occurring in adults ( 92\% in June $2020^{13}$ and $\sim 89 \%$ in December $2020^{14}$ ). We computed the infection fatality rate as the proportion of deaths per 100,000 from a denominator of seroprevalent persons per 100,000 in the corresponding time periods.

\section{Results}

Of the 21,424 persons tested in the first week of January 2021, a majority were men and were older than 65 years of age, similar to the overall US dialysis population (Table 1). Although patients resided in a total of 43 states, 33 states contributed $>30$ patients to the sample. Persons from the South and West regions were modestly overrepresented. Neighborhood race/ethnicity composition closely matched the US dialysis population. Compared to the US adult population, sampled patients were older, more likely male, and more likely to be of non-white race and Hispanic ethnicity.

In January 2021, SARS-CoV-2 RBD seroprevalence estimates were 18.9\% (95\% CI 18.3, 19.5\%) in the sample, $18.7 \%(18.1,19.2 \%)$ standardized to US dialysis, and $21.3 \%(20.3,22.3 \%)$ standardized to US adult population respectively (Table 2). Younger age groups (18-44 years), and persons self-identifying 
medRxiv preprint doi: https://doi.org/10.1101/2021.03.07.21252786; this version posted March 9, 2021. The copyright holder for this preprint (which was not certified by peer review) is the author/funder, who has granted medRxiv a license to display the preprint in perpetuity.

All rights reserved. No reuse allowed without permission.

as Hispanic or living in Hispanic neighborhoods, and persons living in the poorest neighborhoods were among the subgroups with the highest seroprevalence.

We compared these values to observations from patients within the US Renal Care network tested in July 2020. In this subset in July, the sample, dialysis adjusted and US population adjusted seroprevalence rates were $4.4(4.0,4.8), 4.7(4.3,5.2)$, and $5.4(4.6,6.2)$, respectively (supplemental Table 2). Relative to July, January 2021 seroprevalences were 2-fold, 4-fold, and 5-fold higher in the Northeast, Midwest, and South and West respectively (Figure 1). Regional and rural vs. urban seroprevalences varied less than previously (supplemental Figure 1), but striking differences remained by race/ethnicity and poverty. Seroprevalence was $1 \cdot 7$-fold $(95 \%$ CI $1 \cdot 6,1 \cdot 9)$ higher among persons living in majority-Hispanic compared to majority-white neighborhoods, and 2·0-fold (95\% CI 1·8, 2·3) higher among persons living in neighborhoods with $\geq 30 \%$ versus $<10 \%$ of residents living in poverty (Figure 2).

\section{Discussion}

In a January, 2021 nationwide surveillance of SARS-CoV-2 seroprevalence among patients on dialysis, we found that, despite national surges in cases and almost half a million deaths, fewer than one in four US adults had evidence of SARS-CoV-2 antibody. Compared to July 2020, spread of SARS-CoV-2 throughout the US became more uniform across geographic regions, and urban and rural areas. The largest differences in seroprevalences occurred between younger and older age groups, residents of majority Hispanic versus majority white neighborhoods, and residents of poorer versus more affluent neighborhoods. Case detection improved but close to three in four cases remained undiagnosed. Our data emphasize the critical need for prompt, wide-spread vaccination, and ongoing mitigation efforts since on the basis of this seroprevalence evaluation, much of the population still remains vulnerable to SARSCoV-2 infection.

Few up-to-date data exist on SARS-CoV-2 seroprevalence from countries with high numbers of cases and deaths from COVID19. In the US, the Centers for Disease Control (CDC) implemented a large and 
medRxiv preprint doi: https://doi.org/10.1101/2021.03.07.21252786; this version posted March 9, 2021. The copyright holder for this preprint (which was not certified by peer review) is the author/funder, who has granted medRxiv a license to display the preprint in perpetuity.

All rights reserved. No reuse allowed without permission.

geographically diverse longitudinal sero-surveillance using repeated commercial laboratory testing. Our July seroprevalence estimates were in line with those reported using the CDC strategy. ${ }^{15}$ The latest available data from the CDC, however, are from November 2020, prior to the largest surge of cases in the US. Outside of the US, India performed over 15000 home visits in 700 communities testing 29,000 people with plasma nucleocapsid IgG testing between August and September 2020 and estimated seroprevalence of $7 \%$ among adults, at a time when the country had recorded roughly six million cases ${ }^{16}$. In the UK, the Real-time assessment of Community Transmission (REACT) study mailed lateral flow immunoassays to randomly selected UK residents ${ }^{17,18}$. This ongoing study has a wide reach (over 350,000 participants reached by fall 2020), amenable to repeat serosurveillance. In the last iteration prior to vaccine roll out, the authors observed a decline in seroprevalence over time possibly due to rapid decay in the qualitative measure of anti-Spike antibody, limiting the study's ability to estimate overall infection rates in the $\mathrm{UK}^{17}$. Brazilian investigators using blood donor samples in Manaus, Brazil, created a seroprevalence model that incorporated a parameter for antibody decay. Using this strategy, they concluded that $75 \%$ in Manaus had been infected by October $2020 .{ }^{19}$ A later surge of infections in Manaus, however, has raised questions about model assumptions ${ }^{20}$.

Ease of replication, unbiased sampling, and high-quality immunoassays—all features of national dialysis sampling-are crucial to rapid and informative seroprevalence. Nonetheless, our strategy may also have modestly underestimated SARS-CoV-2 cumulative infections for two reasons. First, SARS-CoV-2 antibodies may wane over time. Several large studies, however, including our own performed in this population, indicate that the RBD domain antibody typically persists for at least 4-6 months ${ }^{4,5}$, longer than the nucleocapsid assays used in other seroprevalence studies ${ }^{16,19}$. Second, our current sample underrepresents New York City, a high-risk area, perhaps contributing to a lower seroprevalence than might be otherwise expected in the Northeast region.

Our data reliably assess differences in seroprevalence by patient and community-level characteristics over time. We note the rapid spread of the infection throughout the breadth of the US. Whereas in July 2020 
seroprevalence rates varied from $<1$ to $34 \%$, in January 2021, nearly all sampled states had seroprevalence estimates exceeding $10 \%$ and among the four regions, the range of seroprevalence was narrow (15-21\%). These trends fit with other descriptions of the pandemic, for example in Brazil, where international travel first brought the pandemic to major cities with rapid spread in densely populated areas, but eventual spread occurred throughout the country ${ }^{21}$.

Our estimates for case detection and infection fatality—with infection fatality exceeding $1 \%$ in the Northeast after the first wave in the Spring — match modeled estimates by Yang et al. ${ }^{22}$ The improvement in both parameters since then indicate better detection and treatment, and are generally uniformly spread throughout the US.

Strengths of our study include its unbiased sampling of hard-to-reach populations, reflective of persons most vulnerable to SARS-CoV-2, and the use of a highly specific and sensitive assay for an antibody for which data indicate a prolonged persistence in a majority of infected persons ${ }^{4,5,23}$. This pragmatic approach enables rapid and repeated evaluations. The limitations include lack of data on SARS-CoV-2 rtPCR testing or COVID19 symptoms, and relative under-sampling from the Northeast region.

In summary, using unbiased data from a sentinel population, we estimate that fewer than one in four persons in the US had evidence of SARS-CoV-2 antibody in January 2021, well below the level needed to confer herd immunity. Residents of majority minority and poorer neighborhoods, and younger age groups have substantially higher prevalence of SARS-CoV-2 antibodies. Since these sub-populations overlap with persons expressing high levels of vaccine hesitancy in the $\mathrm{US}^{24,25}$, vaccination campaigns will need to engage these high-risk groups in order to achieve sufficient penetration to reach communitylevel protection against SARS-CoV-2. 
medRxiv preprint doi: https://doi.org/10.1101/2021.03.07.21252786; this version posted March 9, 2021. The copyright holder for this preprint (which was not certified by peer review) is the author/funder, who has granted medRxiv a license to display the preprint in perpetuity.

All rights reserved. No reuse allowed without permission.

Table 1 Comparison of sampled population, US adult dialysis population, and US adult population (January 2021)

\begin{tabular}{|c|c|c|c|c|c|c|}
\hline \multirow[t]{2}{*}{ Patient characteristics } & \multicolumn{2}{|c|}{$\begin{array}{c}\text { Sample population } \\
\text { (January 2021) } \\
\mathrm{N}=21,424\end{array}$} & \multicolumn{2}{|c|}{$\begin{array}{c}\text { US adult } \\
\text { dialysis } \\
\text { population } \\
\mathrm{N}=499,150\end{array}$} & \multirow[t]{2}{*}{$\begin{array}{c}\begin{array}{c}\text { US adult } \\
\text { population } \\
\mathrm{N}=253,815197\end{array} \\
\text { Count }\end{array}$} & \multirow[b]{2}{*}{$\%$} \\
\hline & Count & $\%$ & Count & $\%$ & & \\
\hline \multicolumn{7}{|l|}{ Age } \\
\hline $18-44$ & 2314 & 11 & 60,540 & 12 & $117,499,477$ & 46 \\
\hline $45-64$ & 8635 & 40 & 207,022 & 41 & $83,892,606$ & 33 \\
\hline $65-79$ & 7847 & 37 & 174,341 & 35 & $39,949,825$ & 16 \\
\hline$\geq 80$ & 2668 & 12 & 57,247 & 11 & $12,473,289$ & 5 \\
\hline \multicolumn{7}{|l|}{ Sex } \\
\hline M & 12,265 & 57 & 285,281 & 57 & $123,578,869$ & 49 \\
\hline $\mathrm{F}$ & 9199 & 43 & 213,869 & 43 & $130,236,328$ & 51 \\
\hline Race and Ethnicity*\& & & $\&$ & & & & \\
\hline Hispanic & 2945 & 18 & 87,611 & 18 & $60,861,275$ & 19 \\
\hline Non-Hispanic white & 6311 & 37 & 203,421 & 41 & $197,202,727$ & 60 \\
\hline Non-Hispanic Black & 4875 & 29 & 173,190 & 35 & $39,717,152$ & 12 \\
\hline Non-Hispanic Other & 2834 & 17 & 34,928 & 7 & $28,493,202$ & 9 \\
\hline \multicolumn{7}{|c|}{ ZCTA Majority Race and Ethnicity* ${ }^{*+}$} \\
\hline Non-Hispanic white & 6481 & 30 & 206,678 & 41 & $189,968,192$ & 58 \\
\hline Non-Hispanic Black & 1504 & 7 & 54,999 & 11 & $12,550,083$ & 4 \\
\hline Hispanic & 4023 & 19 & 52,953 & 11 & $26,310,796$ & 8 \\
\hline Hispanic and Black & 2321 & 11 & 43,396 & 9 & $17,238,911$ & 5 \\
\hline Integrated & 7135 & 33 & 140,781 & 28 & $80,206,374$ & 25 \\
\hline \multicolumn{7}{|l|}{ Region } \\
\hline Northeast & 2113 & 10 & 78,619 & 16 & $44,519,465$ & 18 \\
\hline South & 10857 & 50 & 214,974 & 43 & $96,250,597$ & 38 \\
\hline Midwest & 2055 & 10 & 94,490 & 19 & $52,876,708$ & 21 \\
\hline West & 6439 & 30 & 111,067 & 22 & $60,168,427$ & 24 \\
\hline
\end{tabular}

US adult population in 2018, US adult patients on dialysis population as of January 12017.

*Race, ethnicity, and ZCTA Majority Race and Ethnicity computed for total U.S. 2018 population N=326,274,356.

${ }^{\&}$ Proportions are reported for persons with available data; 4505 (21) in the sample were missing race and ethnicity.

^343 and 583 people in the U.S. Renal Data System and sample populations missing data on ZCTA Majority Race/Ethnicity due to missing zip code respectively. ${ }^{+}$ZCTA Majority defined as population in ZCTA $\geq 60$ Hispanic, Non-Hispanic Black, or Non Hispanic White; if in remainder ZCTAs Hispanic and Black population exceeded $\geq 60$, ZCTA defined as 'Hispanic and Black', else as 'Other'.

Abbreviations: ZCTA-zip code tabulation area 
medRxiv preprint doi: https://doi.org/10.1101/2021.03.07.21252786; this version posted March 9, 2021. The copyright holder for this preprint (which was not certified by peer review) is the author/funder, who has granted medRxiv a license to display the preprint in perpetuity. All rights reserved. No reuse allowed without permission.

Table 2 Seroprevalence of SARS-CoV2 antibodies in the study sample and standardized to US dialysis and US adult population in January 2021

\begin{tabular}{|c|c|c|c|c|c|}
\hline & \multicolumn{2}{|c|}{$\begin{array}{l}\text { Unweighted sample } \\
\text { (January 2021) }\end{array}$} & \multirow{2}{*}{$\begin{array}{c}\text { Standardized to } \\
\begin{array}{c}\text { US adult dialysis } \\
\text { population }\end{array} \\
\text { Seropositive } \% \\
\end{array}$} & \multirow{2}{*}{$\begin{array}{c}\text { Standardized to } \\
\begin{array}{c}\text { US adult } \\
\text { population }\end{array} \\
\text { Seropositive \% } \\
\end{array}$} & \multirow{2}{*}{$\begin{array}{c}\text { Seropositive } \\
\text { persons per } \\
100,000^{\Omega} \\
\text { Count }\end{array}$} \\
\hline & Count & Seropositive \% & & & \\
\hline \multicolumn{6}{|l|}{ Age** } \\
\hline $18-44$ & 591 & $25.5(23.6,27.7)$ & $25.5(23.7,27.5)$ & $25.3(23.3,27.4)$ & 23328 \\
\hline $45-64$ & 1824 & $21.1(20.2,22.1)$ & $20.3(19.4,21.2)$ & $19.9(18.9,20.8)$ & 19861 \\
\hline $65-79$ & 1276 & $16.3(15.4,17.2)$ & $15.9(15.0,16.7)$ & $15.9(15.0,16.8)$ & 15884 \\
\hline$\geq 80$ & 370 & $13.9(12.5,15.4)$ & $14.1(12.7,15.6)$ & $14.5(13.1,16.2)$ & 14527 \\
\hline \multicolumn{6}{|l|}{ Sex* } \\
\hline M & 2250 & $18.3(17.6,19.1)$ & $18.1(17.4,18.9)$ & $20.7(19.5,22.0)$ & 19934 \\
\hline $\mathrm{F}$ & 1811 & $19.7(18.8,20.6)$ & $19.3(18.5,20.2)$ & $21.9(20.5,23.5)$ & 21189 \\
\hline \multicolumn{6}{|c|}{ Race and Ethnicity** } \\
\hline Hispanic & 763 & $25.9(24.1,27.8)$ & $26.2(24.5,27.9)$ & $29.0(26.2,31.8)$ & 15495 \\
\hline Non-Hispanic white & 1084 & $17.2(16.2,18.2)$ & $16.6(15.6,17.6)$ & $17.6(16.0,19.2)$ & 6189 \\
\hline Non-Hispanic Black & 885 & $18.2(17.0,19.4)$ & $18.1(17.0,19.3)$ & $21.0(18.9,23.1)$ & 32439 \\
\hline Other & 374 & $13.2(11.9,14.6)$ & $13.3(12.0,14.7)$ & $17.0(14.3,19.7)$ & 16315 \\
\hline \multicolumn{6}{|c|}{ ZCTA Majority Race/Ethnicity ${ }^{+* *}$} \\
\hline Hispanic & 1010 & $25.1(23.6,26.4)$ & $25.2(23.9,26.6)$ & $27.4(25.3,29.7)$ & 7450 \\
\hline Non-Hispanic white & 993 & $15.3(14.4,16.3)$ & $15.0(14.1,16.0)$ & $16.4(14.8,18.1)$ & 41150 \\
\hline Non-Hispanic Black & 306 & $20.3(18.3,22.4)$ & $20.4(18.2,22.6)$ & $26.5(22.2,30.9)$ & 40574 \\
\hline Hispanic and Black & 540 & $23.3(21.5,25.0)$ & $23.8(22.1,25.7)$ & $26.4(23.5,29.5)$ & 37928 \\
\hline Integrated & 1212 & $17.0(16.1,17.9)$ & $17.5(16.5,18.5)$ & $20.8(19.0,22.5)$ & 19574 \\
\hline \multicolumn{6}{|l|}{ Region** } \\
\hline Northeast & 323 & $15.3(13.8,16.8)$ & $15.6(14.1,17.1)$ & $19.0(16.1,21.9)$ & 18370 \\
\hline South & 2257 & $20.8(20.0,21.6)$ & $21.0(20.2,21.8)$ & $24.2(22.9,25.4)$ & 23290 \\
\hline Midwest & 341 & $16.6(15.0,18.2)$ & $16.7(15.1,18.4)$ & $19.9(17.0,22.8)$ & 19199 \\
\hline West & 1140 & $17.7(16.7,18.6)$ & $17.9(17.0,18.9)$ & $19.8(18.2,21.3)$ & 19086 \\
\hline \multicolumn{6}{|c|}{ ZCTA poverty level ${ }^{\# * *}$} \\
\hline$<10 \%$ & 776 & $13.3(12.4,14.2)$ & $13.5(12.6,14.5)$ & $15.6(13.9,17.5)$ & 8135 \\
\hline $10 \%$ to $<20 \%$ & 1517 & $18.8(17.9,19.6)$ & $18.8(17.9,19.7)$ & $21.0(19.4,22.6)$ & 16364 \\
\hline $20 \%$ to $<30 \%$ & 1101 & $22.7(21.5,23.9)$ & $22.4(21.1,23.6)$ & $26.0(23.9,28.2)$ & 27489 \\
\hline$\geq 30 \%$ & 666 & $24.8(23.2,26.5)$ & $23.8(22.1,25.5)$ & $26.1(23.3,29.0)$ & 38123 \\
\hline \multicolumn{6}{|c|}{ ZCTA rural or urban status } \\
\hline Dense urban & 3332 & $18.7(18.1,19.4)$ & $18.5(17.9,19.2)$ & $21.4(20.3,22.5)$ & 17773 \\
\hline Metropolitan & 269 & $16.7(14.8,18.8)$ & $15.7(14.0,17.6)$ & $16.8(13.7,19.9)$ & 10007 \\
\hline Micropolitan & 247 & $23.0(20.3,26.1)$ & $21.2(18.8,23.9)$ & $21.6(17.7,25.5)$ & 9142 \\
\hline Small town or rural & 205 & $22.0(19.2,25.2)$ & $22.2(19.4,25.3)$ & $25.1(20.1,30.0)$ & 12196 \\
\hline Overall & 4061 & $18.9(18.3,19.5)$ & $18.7(18.1,19.2)$ & $21.3(20.3,22.3)$ & 20578 \\
\hline $\begin{array}{l}\text { *different a } \\
\text { using all ad } \\
\text { States Rena } \\
\text { per } 100,000 \\
\geq 60 \% \text { Hisp } \\
\text { exceeded } \geq\end{array}$ & $\begin{array}{l}\text { lifferent } \\
\text { ialysis } f \\
\text { latabase } \\
\text { ated as } s \\
\text { anic Bla } \\
\text { fined as }\end{array}$ & $\begin{array}{l}\text { } 0.0001 \text { for the samp } \\
\text { treatment of end sta } \\
499,150) \text {. }{ }^{\circ} \text { Standardi } \\
\text { ardized count/categor } \\
\text { r Non-Hispanic whit }\end{array}$ & $\begin{array}{l}\text { pulation. " } \\
\text { dney disease on Jan } 1 \\
\text { o the U.S. population } \\
\text { 100,000. }{ }^{+} \text {ZCTA M } \\
\text { n remainder ZCTAs }\end{array}$ & $\begin{array}{l}\text { o the USA dialysis po } \\
017 \text { identified through } \\
\text { gg ACS } 2018 \text { data }{ }^{\Omega} \mathrm{Se} \\
\text { ty defined if populati } \\
\text { anic and Black popul }\end{array}$ & $\begin{array}{l}\text { tion } \\
\text { United } \\
\text { sitivity } \\
\text { ZCTA }\end{array}$ \\
\hline
\end{tabular}


medRxiv preprint doi: https://doi.org/10.1101/2021.03.07.21252786; this version posted March 9, 2021. The copyright holder for this preprint (which was not certified by peer review) is the author/funder, who has granted medRxiv a license to display the preprint in perpetuity.

All rights reserved. No reuse allowed without permission.

\section{Figure Legends:}

Figure 1: SARS-CoV-2 seroprevalence by US region in January 2021, with comparison to sampled states between July 2020

Overall seroprevalence was between $15-21 \%$ across all regions, with the highest seroprevalence in the US South. Compared to July data from patients dialyzing in the same dialysis facilities, seroprevalence was 1.8-fold (95\% CI 1.5, 2.3) higher in the Northeast, 4.1 -fold (95\% CI 3.0, 5.7) higher in the Midwest and 4.6-fold (95\% CI 3.9, 5.5) higher in the West. The largest increase in seroprevalence was observed in the South (5.1-fold (95\% CI 4.5, 5.8)). All 43 states in which patients resided are listed in the figure but data are presented only for states with at least 30 persons in the January sample $(n=33)$.

Figure 2: Case detection and infection fatality rates in January 2021, with comparison to July 2020

The detected cases per 100,000 between June-December 2020 were 23\% of estimated seroprevalent persons and deaths attributed to COVID19 in January 2021 (range by region 17-30\% in the Northeast and Midwest respectively). This proportion was an increase from detected cases being $14 \%$ of estimated seroprevalent persons and deaths attributed to COVID19 in July 2020 (range by region $13 \%$ to $16 \%$ in the West and Midwest respectively). The infection fatality rate in January 2021 was $0.3 \%$ (range $0.3-0.4 \%$ ), compared with $0.7 \%$ in July 2020 (range $0.4-1.3 \%$ ).

\section{Funding}

Ascend Clinical Laboratory funded the remainder plasma sampling.

\section{Declaration of Interest}

LC, PH, RK and PB are employed by Ascend Clinical Laboratories; MD and GB are employed by US Renal Care. GC is on the Board of Satellite Healthcare, a not-for-profit dialysis organization.

\section{Author Contributions}

SA assisted with cleaning and analysis planning, and manuscript writing. MMR developed analysis plan, supervised data analysis and contributed to manuscript writing. JH and PG undertook data cleaning and analysis, including linkage to external data and figure generation, and contributed to manuscript writing. LC and PH undertook sample processing and data preparation. GB and MD participated in study planning and sample and de-identified data provision. RK selected seroprevalence testing, supervised sample processing, and contributed to manuscript writing. PB coconceived study, and secured seroprevalence testing. JP supervised study analysis plan, identified relevant external data, data interpretation, and supervised manuscript writing. SB assisted with data interpretation. GMC co-conceived study, supervised study analysis plan, and co-wrote manuscript. 
medRxiv preprint doi: https://doi.org/10.1101/2021.03.07.21252786; this version posted March 9, 2021. The copyright holder for this preprint (which was not certified by peer review) is the author/funder, who has granted medRxiv a license to display the preprint in perpetuity.

All rights reserved. No reuse allowed without permission.

References

1. Centers for Disease Control and Prevention. CDC COVID Data Tracker. https://covidcdcgov/covid-data-tracker/\#cases casesper100klast7days. 2021.

2. Dong E, Du H, Gardner L. An interactive web-based dashboard to track COVID-19 in real time. Lancet Infect Dis. 2020;20(5):533-534.

3. Oran DP, Topol EJ. Prevalence of Asymptomatic SARS-CoV-2 Infection A Narrative Review. Annals of Internal Medicine. 2020;173(5):362-+.

4. Gudbjartsson DF, Norddahl GL, Melsted P, et al. Humoral Immune Response to SARS-CoV-2 in Iceland. N Engl J Med. 2020;383(18):1724-1734.

5. Wajnberg A, Amanat F, Firpo A, et al. Robust neutralizing antibodies to SARS-CoV-2 infection persist for months. Science. 2020.

6. Poland GA, Ovsyannikova IG, Kennedy RB. SARS-CoV-2 immunity: review and applications to phase 3 vaccine candidates. Lancet. 2020;396(10262):1595-1606.

7. Duysburgh E, Mortgat L, Barbezange $C$, et al. Persistence of IgG response to SARS-CoV-2. Lancet Infect Dis. 2020.

8. Iyer AS, Jones FK, Nodoushani A, et al. Persistence and decay of human antibody responses to the receptor binding domain of SARS-CoV-2 spike protein in COVID-19 patients. Sci Immunol. 2020;5(52).

9. Anand S, Montez-Rath M, Han J, et al. Prevalence of SARS-CoV-2 antibodies in a large nationwide sample of patients on dialysis in the USA: a cross-sectional study. Lancet. 2020.

10. U.S. Food \& Drug Administration. EUA Authorized Serology Test Performance. https://wwwfdagov/medical-devices/coronavirus-disease-2019-covid-19-emergency-useauthorizations-medical-devices/eua-authorized-serology-test-performance. 2020.

11. Annual Data Report. USRDS; 2018. Accessed June 152020.

12. U.S. Census Bureau American Community Survey. 2018 American Community Survey 5 Year Estimates, Tables B03002, S1701, and B01003. Generated by Maria Montez-Rath; using datacensusgov; <https://datacensusgov/cedsci/>; (10 July 2020).

13. Sisk B, Cull W, Harris JM, Rothenburger A, Olson L. National Trends of Cases of COVID-19 in Children Based on US State Health Department Data. Pediatrics. 2020;146(6).

14. Centers for Disease Control and Prevention. Demographic Trends of COVID-19 cases abd deaths in the US reported to CDC https://covidcdcgov/covid-data-tracker/\#demographics. 2021; Last accessed February 6, 2021.

15. Bajema KL, Wiegand RE, Cuffe K, et al. Estimated SARS-CoV-2 Seroprevalence in the US as of September 2020. JAMA Intern Med. 2020.

16. Murhekar MV, Bhatnagar T, Selvaraju S, et al. SARS-CoV-2 antibody seroprevalence in India, August-September, 2020: findings from the second nationwide household serosurvey. Lancet Glob Health. 2021;9(3):e257-e266.

17. Ward H, Cooke G, Atchison C, et al. Declining prevalence of antibody positivity to SARS-CoV2: a community study of 365,000 adults. medRxiv. 2020:2020.2010.2026.20219725.

18. Ward $\mathrm{H}$, Atchison $\mathrm{C}$, Whitaker M, et al. Antibody prevalence for SARS-CoV-2 following the peak of the pandemic in England: REACT2 study in 100,000 adults. medRxiv. 2020:2020.2008.2012.20173690.

19. Buss LF, Prete CA, Jr., Abrahim CMM, et al. Three-quarters attack rate of SARS-CoV-2 in the Brazilian Amazon during a largely unmitigated epidemic. Science. 2021;371(6526):288-292.

20. Sabino EC, Buss LF, Carvalho MPS, et al. Resurgence of COVID-19 in Manaus, Brazil, despite high seroprevalence. Lancet. 2021;397(10273):452-455. 
medRxiv preprint doi: https://doi.org/10.1101/2021.03.07.21252786; this version posted March 9, 2021. The copyright holder for this preprint

(which was not certified by peer review) is the author/funder, who has granted medRxiv a license to display the preprint in perpetuity.

All rights reserved. No reuse allowed without permission.

21. Candido DS, Claro IM, de Jesus JG, et al. Evolution and epidemic spread of SARS-CoV-2 in Brazil. Science. 2020;369(6508):1255-1260.

22. Yang $W$, Kandula S, Huynh M, et al. Estimating the infection-fatality risk of SARS-CoV-2 in New York City during the spring 2020 pandemic wave: a model-based analysis. Lancet Infect Dis. 2021;21(2):203-212.

23. Ripperger TJ, Uhrlaub JL, Watanabe M, et al. Orthogonal SARS-CoV-2 Serological Assays Enable Surveillance of Low-Prevalence Communities and Reveal Durable Humoral Immunity. Immunity. 2020;53(5):925-933 e924.

24. Szilagyi PG, Thomas K, Shah MD, et al. National Trends in the US Public's Likelihood of Getting a COVID-19 Vaccine-April 1 to December 8, 2020. JAMA. 2020.

25. Omer SB, Yildirim I, Forman HP. Herd Immunity and Implications for SARS-CoV-2 Control. JAMA. 2020;324(20):2095-2096. 
Figure 1: SARS-

\section{CoV-2}

seroprevalence by

US region and

sampled states in

January 2021, with

comparison to

data from July

2020

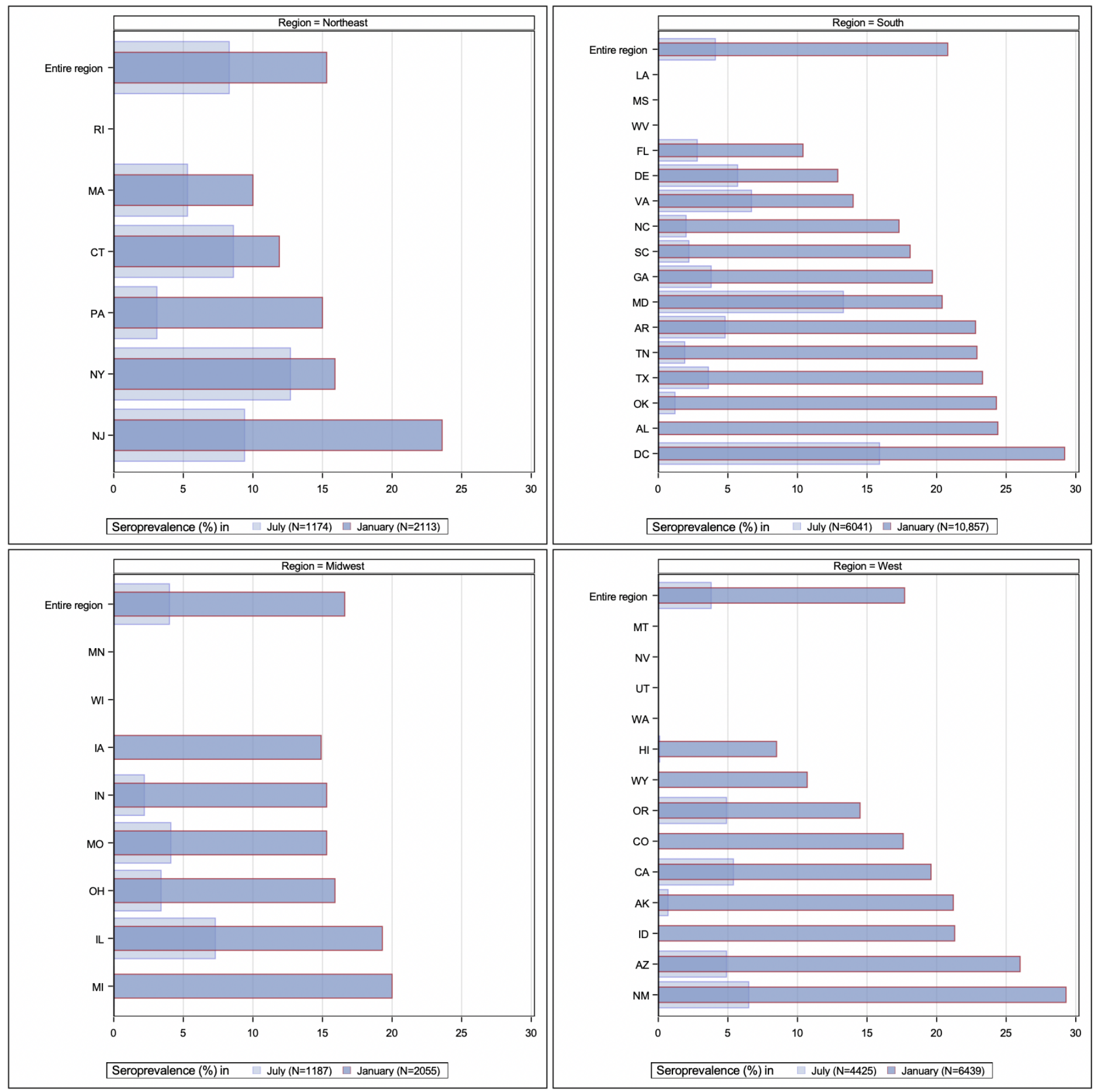


Figure 2: Case

detection and

infection fatality

rates in January

2021, with

comparison to July

2020
Northeast

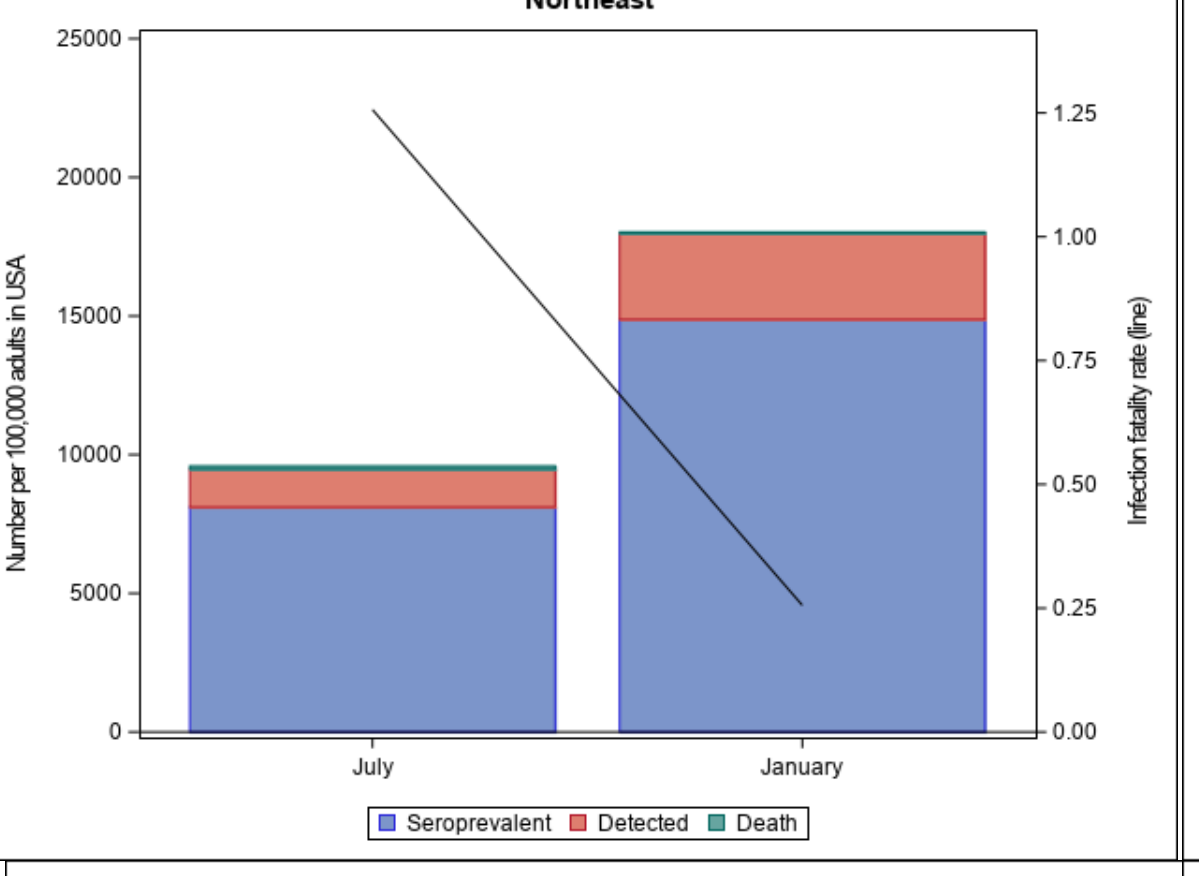

Midwest

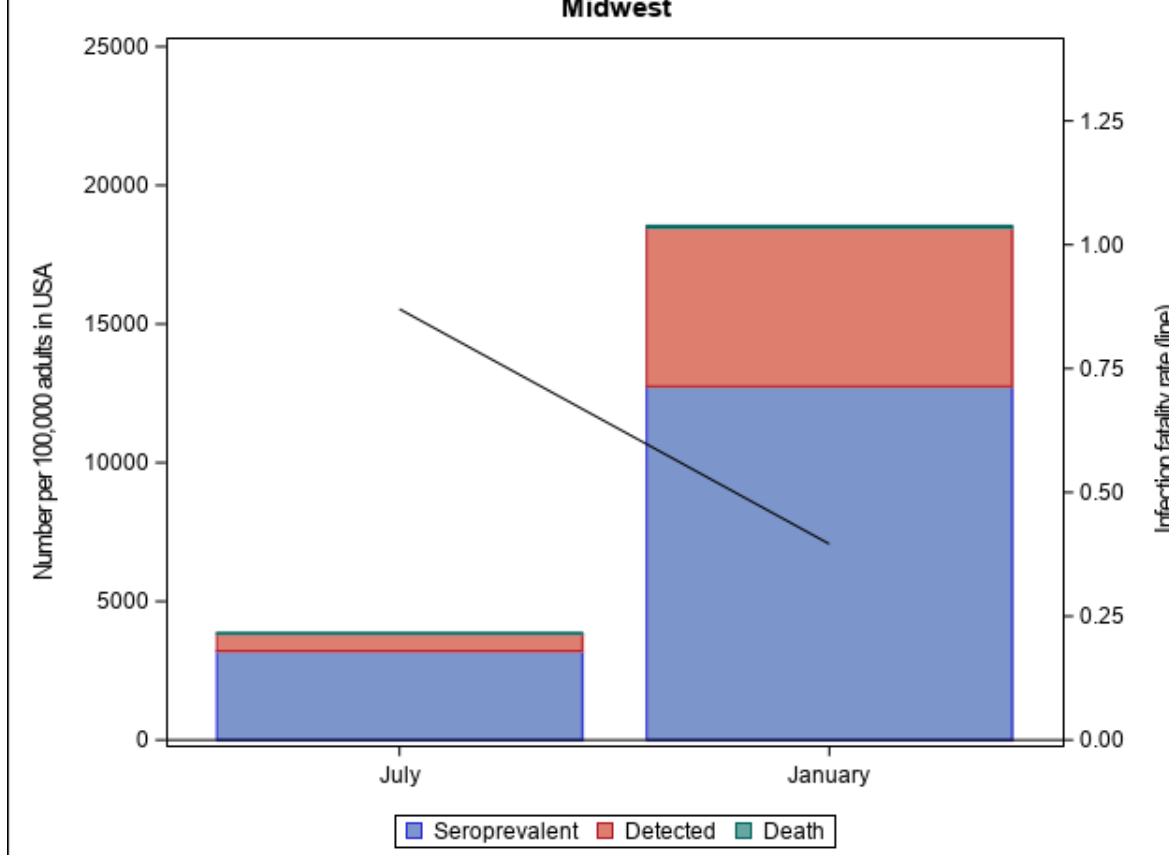

South

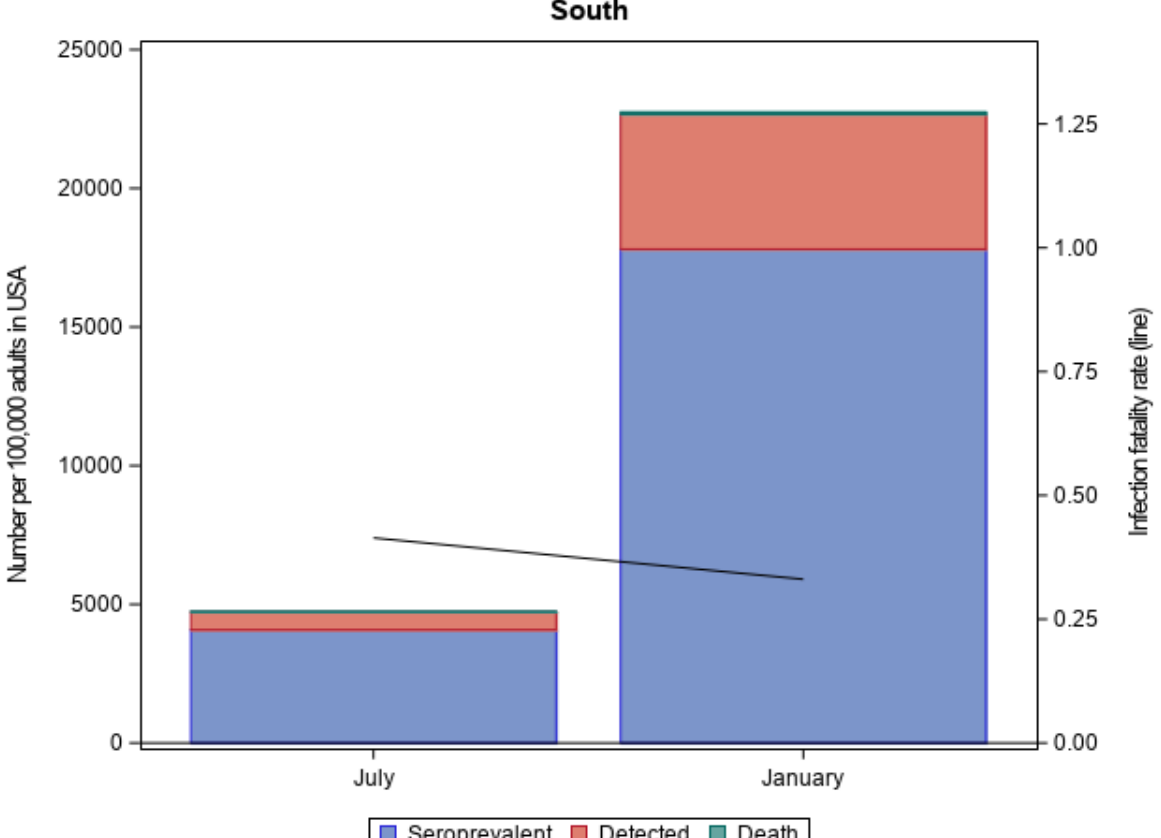

$\square$ Seroprevalent $\square$ Detected $\square$ Death

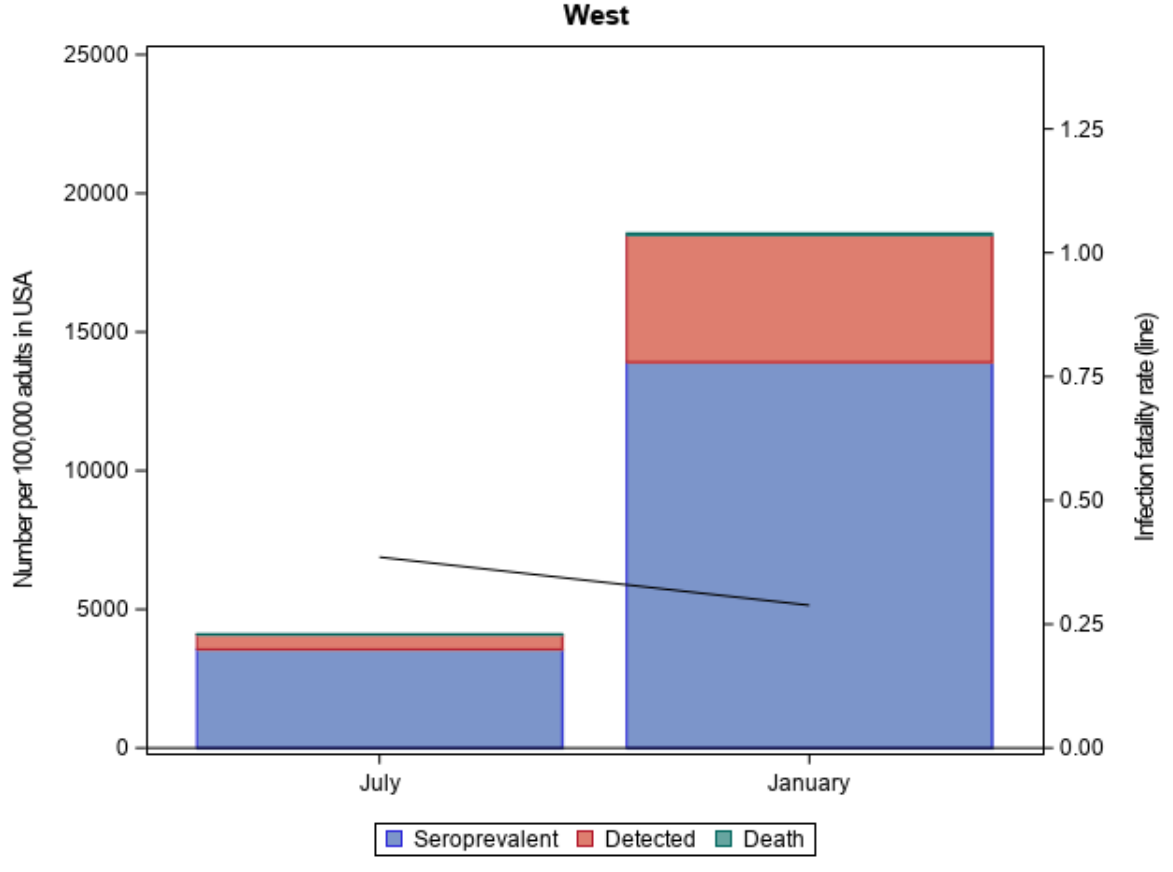


Supplemental

Figure 1:

Neighborhood

level

characteristics associated with SARS-CoV-2

seroprevalence in January 2021

with

comparisons to July 2021

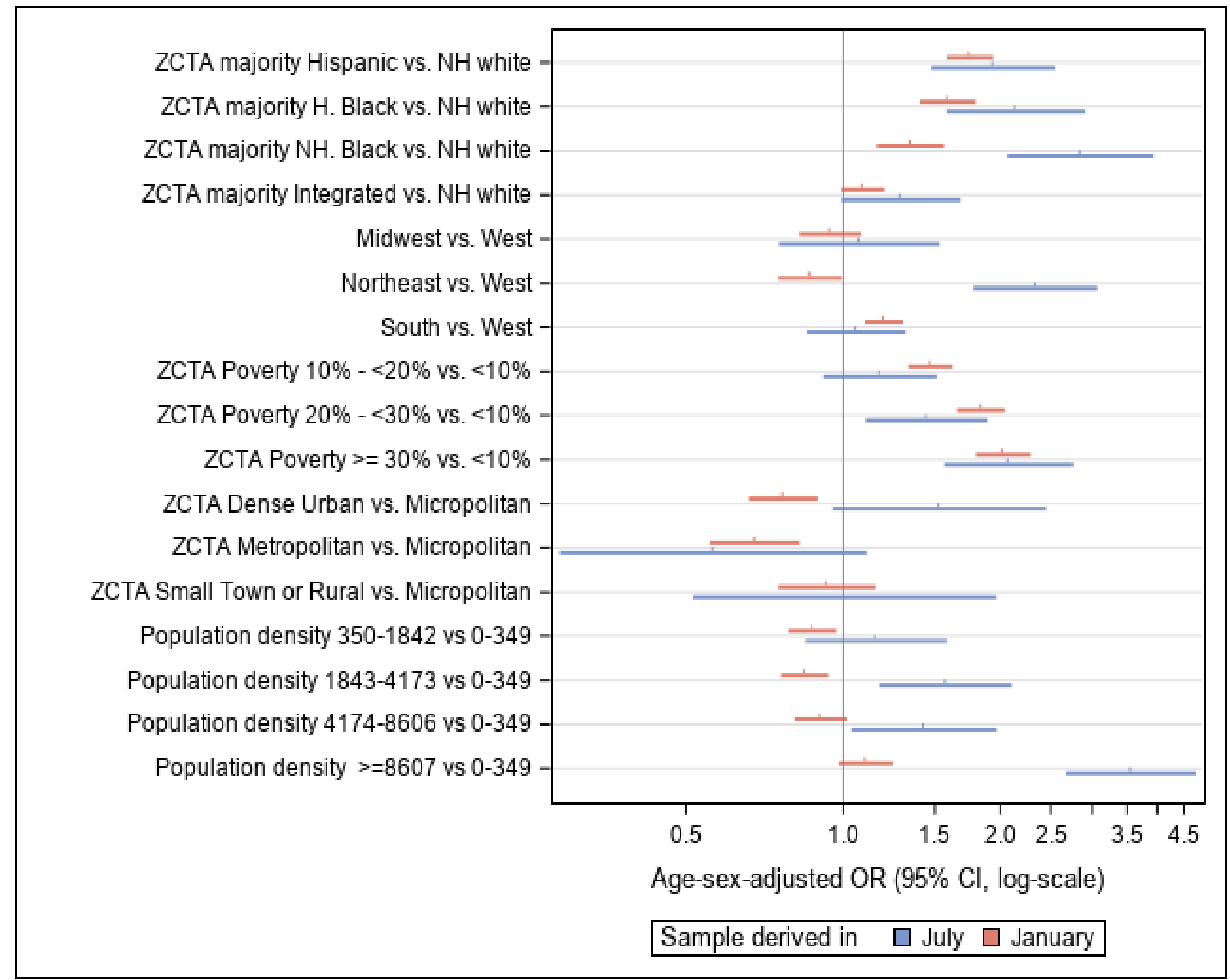

ZCTA majority H. Black vs. NH white ZCTA majority NH. Black vs. NH white ZCTA majority Integrated vs. NH white Midwest vs. West ortheast vs. West South vs. West ZCTA Poverty $10 \%$ - $<20 \%$ vs. $<10 \%$ ZCTA Poverty $20 \%-<30 \%$ vs. $<10 \%$ A Small Town or Rural vs. Micropolitan Population density $1843-4173$ vs 0-349 opulation density $4174-8606$ vs $0-349$ Population density $>=8607$ vs $0-349$ 